This item was submitted to Loughborough's Research Repository by the author.

Items in Figshare are protected by copyright, with all rights reserved, unless otherwise indicated.

From passive to active: the changing relationship between supporters and football clubs

PLEASE CITE THE PUBLISHED VERSION

http://dx.doi.org/10.1080/14660970.2010.497348

PUBLISHER

(c) Taylor \& Francis

VERSION

AM (Accepted Manuscript)

LICENCE

CC BY-NC-ND 4.0

REPOSITORY RECORD

Cleland, Jamie. 2019. "From Passive to Active: The Changing Relationship Between Supporters and Football Clubs". figshare. https://hdl.handle.net/2134/12129. 
This item was submitted to Loughborough's Institutional Repository (https://dspace.lboro.ac.uk/) by the author and is made available under the following Creative Commons Licence conditions.

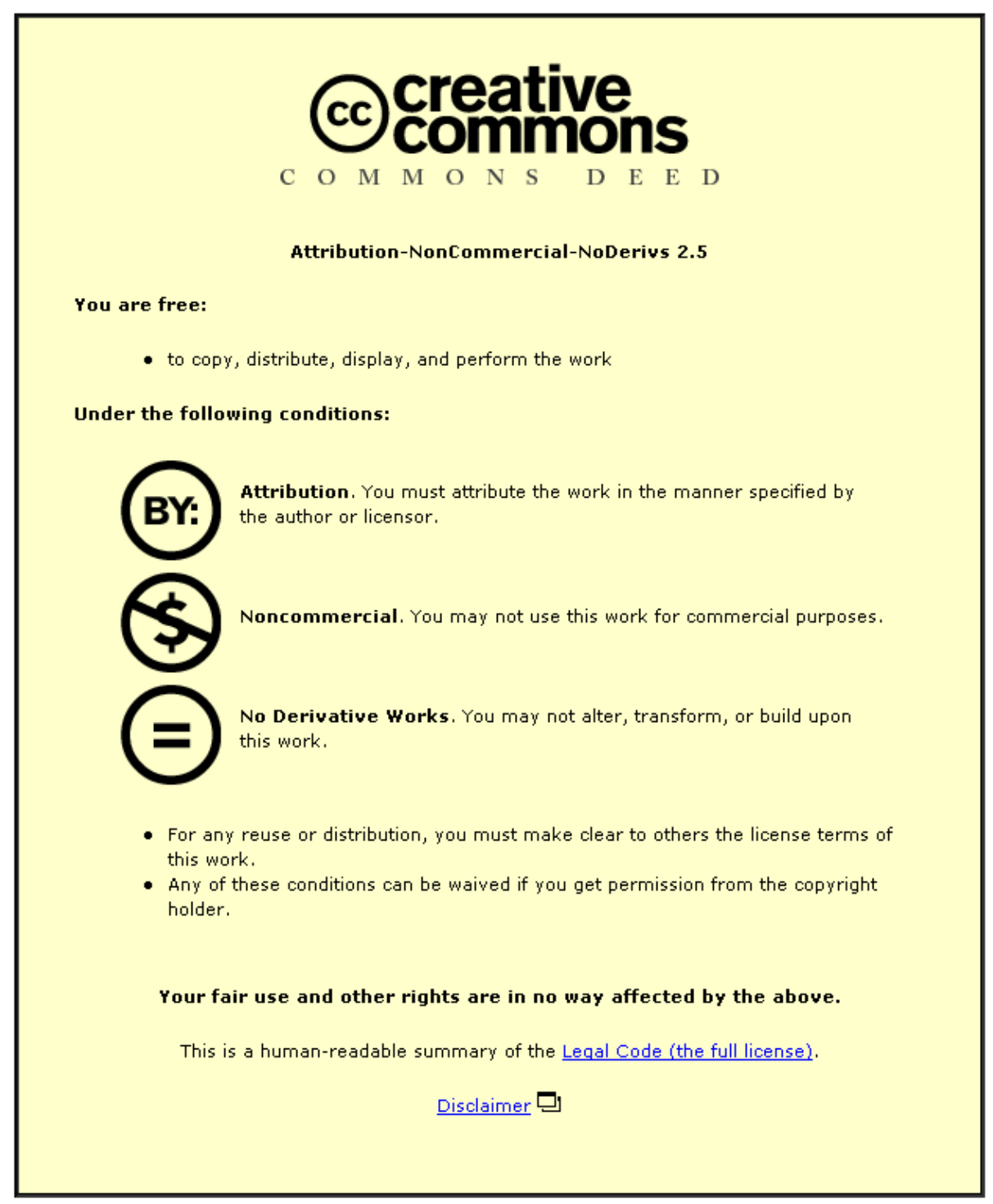

For the full text of this licence, please go to: http://creativecommons.org/licenses/by-nc-nd/2.5/ 


\title{
'From Passive to Active: The Changing Relationship between Supporters and Football Clubs'
}

\begin{abstract}
$\underline{\text { Abstract }}$
The changing relationship between clubs and supporters has been the subject of recent debate but has received relatively limited empirical analysis based on case study research. This article draws on interviews and a questionnaire fan survey to assess the extent to which four football clubs had developed mechanisms to include 'active' supporters in club-related decisions. The article then examines the strategies put in place by each club to encourage supporter involvement and whether they have been successful in their actions. The results indicated that supporters of clubs which encouraged an inclusive relationship through the opportunity of two-way dialogue expressed greater satisfaction than supporters of clubs which maintained one-way dialogue. The article concludes by suggesting that those clubs which are seen to exclude 'active' supporters could face long-term financial consequences if they continue to operate in this way.
\end{abstract}

\section{Introduction}

Over the last twenty years there have been many changes to football that have affected the relationship between clubs and fans. These include the rise in fanzines and supporter organisations, the formation of the Premier League in 1992 and breakaway from the Football League, the rise of 'new' media and subsequent interest and investment in top-flight football, the increasing number of overseas investors and the debate surrounding the 'new' definitions of modern supporters. Whilst it has been argued elsewhere that the economic importance of supporters to football clubs is important,[1] it fails to capture the social and political nature of this relationship, such as the importance of developing an identity with 'their' club and the wider aspects of social responsibility.[2]

This article offers a novel and unique contribution to modern day football research as it comprehensively focuses on the collection and analysis of empirical data to assess changes in the club-fan relationship. With limited empirical attention paid to the club-fan relationship, the objective of this article is to analyse the extent to which the 'active' (rather than 'passive') nature of supporters at four football clubs has led to greater levels of inclusion. For the purposes of this article, inclusion refers to the development of strategies where supporters can 
communicate and interact with football club hierarchies to have an influence on the decisions clubs make. Exclusion refers to the maintenance of one-way dialogue from a club to its supporters with very little opportunity to engage and interact with club personnel.

It shall be argued that those clubs that are more inclusive benefit as 'active' supporters are more likely to feel in closer touch as their voice is being heard through the opportunities created for two-way dialogue (such as fans' forums). In terms of categorising supporters in the ways in which they communicate and interact with clubs, 'passive' refers to those who do not engage in any debate with clubs or supporter organisations and 'active' refers to those who actively engage with clubs and supporter organisations. A large majority of fans remain 'passive' in their interaction and communication with a particular club but there are also 'active' fans who could potentially disengage if they feel that their voice is not being heard.

To assist in addressing the research objective, the club-fan relationship is conceptualised as a continuum. In political science, this form of analysis is often referred to as a 'one-axis model', allowing for the rough approximation of plotting political parties, ideologies and politicians along a left-to-right political spectrum through the content analysis of documents and survey work.[3] Therefore, the changes in the club-fan relationship are analysed in terms of the level of inclusion or exclusion evident at four football club case studies as this may not be the same for each club:

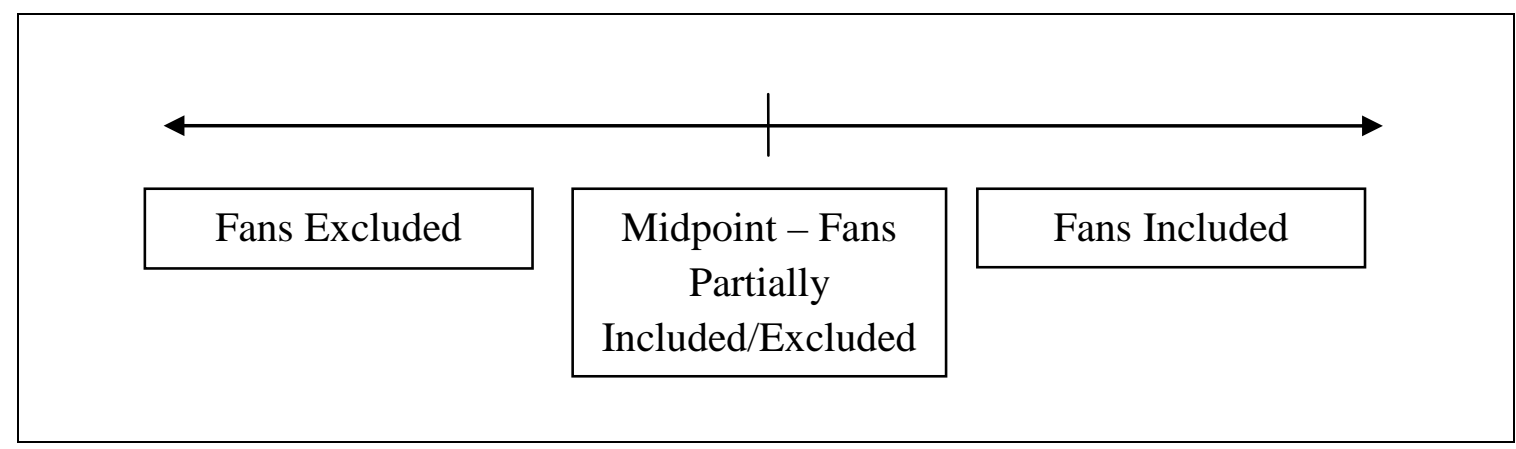




\section{Background}

Historically, the relationship between clubs and supporters was one of exclusion. Many clubs had (and still have) financial difficulties, and it was only public and private donations from their supporters and the local community that kept them in business. Not surprisingly (and again similar to modern times), the contributions made at the time were seen as essential with most clubs relying on income other than what they generated from gate receipts. Yet despite these generous donations, many clubs never reciprocated the goodwill gesture given to them by supporters and in the main continued to exclude them. To try and force more inclusion at clubs the Northampton Town Supporters Club sent letters to other supporters' clubs suggesting that one body should represent all of them and thus the National Federation of Football Supporters' Clubs (NFFSC) was formed in 1927, representing an 'official' part of football fandom.[4]

Despite the establishment of the NFFSC and its intention to recognise supporters more, clubs continued to exclude fans. If a supporter wanted to protest about club policy they could only do two things: either 'vote with their feet' and stay away, or join post-match demonstrations. Gradually, supporters did 'vote with their feet' and significant numbers began to leave the game in the middle to latter part of the twentieth century. For example, attendances began to decline from a 1948 peak of 41.2m to 16.3m in 1986.[5] The reasons for this decline included the increase in media coverage, poor relations with clubs, dilapidated stadia facilities and more disposable income which resulted in money being spent on other activities rather than football.[6]

At the same time, and again highlighting changes in the relationship between clubs and fans, some younger supporters changed allegiances from lower league teams to bigger teams as these matches were being covered more on television after the launch of Match of the Day in 1964.[7] Therefore, the relationship between fans and the media affected, in some 
ways, the relationship between clubs and supporters. This was apparent in research reported by Russell which outlined that all four professional divisions witnessed a decline in average attendances over this period, although the old First Division (now the Premier League) lost the least number of fans.[8]

\section{Active/Passive Debate}

Since the 1980s, academic interest in football supporters and their relationship with clubs has grown. Part of this interest stems from the 'active/passive' debate concerning the changing relationship between football supporters and the media as the development of 'new' media (such as the Internet, satellite television and mobile phones) has transformed the opportunity for two-way dialogue pre and post match.[9] Abercrombie and Longhurst identified three paradigms in the media-audience relationship: behavioural; incorporation/resistance; and spectacle/performance.[10] Abercrombie and Longhurst termed the first paradigm behavioural and suggest that it occurred when the audience accepted or passively absorbed information that was provided to them by the media.[11] Over time, this was superseded by the incorporation/resistance paradigm because it viewed the audience as more active in their consumption as they either reinterpreted or rejected messages from the media. Finally, due to contradictions within the incorporation/resistance paradigm and the changing nature of the audience Abercrombie and Longhurst suggest that it is gradually being superseded by the spectacle/performance paradigm because the audience is becoming more 'skilled' in their consumption of the many media sources that now exist.[12]

As well as focusing on the media-fan relationship, the 'active/passive' debate also applies to the club-fan relationship. It has been stated that this developed out of an analysis to supporter resistance regarding the previously discussed changes in the modern game.[13] Whilst he does not suggest a simple dichotomy of football supporters, Redhead highlights the conflicting nature of 'participatory' and 'passive' forms of football fandom by referring to the 
changing nature of fans in the 1980s.[14] For example, de-industrialisation and the rise of the service sector economy became fundamental in reducing the industrial working class and expanding the amount of white-collar workers in society, thus changing the demographics of the football crowd.[15] Redhead argues that this led to 'participatory' (or 'active') supporters through the development of fanzines and supporter organisations and 'passive' supporters as a result of the increasing number of fans arising from consumer products and television coverage (most notably BSkyB).

Whilst the majority of research on sport audiences in Britain focuses on the incorporation/resistance paradigm, in modern football, Crawford supports the spectacle/performance paradigm as he believes that 'cultural texts' are available for fans to shape and develop their own identities.[16] For example, some fans have become 'proactive collaborators' in consuming and producing their own texts and have ceased to be 'passive disciples'.[17] One aspect of this has been the personalised accounts of fandom that offer insights into cultural issues like identity and gender in the context of their football life. The best example of this is Nick Hornby's Fever Pitch, where he charts his life as a supporter of Arsenal. Boyle and Haynes interpret this style of writing as evidence of the changing social, economic and class status of modern football, with middle class views replacing the traditional working class area of popular culture.[18]

\section{Fan/Club Relationship Changes}

To put Redhead's thoughts into context, during the latter part of the 1980s many fans felt that they were being neglected and ignored by clubs and the game's authorities and they began to devise ways that forced them to be recognised. The only media sources available to fans at this time were newspapers, television and radio; all of which fans felt were portraying them negatively and not listening to their concerns about the game. One reason behind this negative publicity could be attributed to the disasters that occurred in the 1980s, with the 
behaviour of fans blamed for causing many of them to occur (such as the European Cup Final at Heysel in 1985 between Liverpool and Juventus where 39 fans died as a result of fighting). It was at this time that a number of fans decided to act upon this negative portrayal by developing fanzines where they felt included and could share their fears and ideas about the game.[19]

It was argued by Jary et al. that 'the editors of fanzines were united in the opinion that the game ought to be theirs, not the private property of businessmen and remote administrators, or the plaything of the press or the police and politicians'.[20] Thus, fanzines were introduced because they provided a forum for fans to express their views on the administrators running the game, often labelling them out of touch with the traditional supporter who enjoyed standing on the terraces. The success of fanzines is evident by their continued presence at football grounds today, with a number of them also producing fanzine websites, often called e-zines or netzines. One of the reasons for their success is that over the course of their existence they have established themselves as an information source for fans and have provided opportunities for fans to actively air their views.

Another feature that developed out of the post-1985 football culture was the emergence of 'active' independent fan movements, starting with a new type of supporter association, the Football Supporters' Association (FSA).[21] By providing an avenue for public expression the FSA argued that fans should have a much closer involvement in 'their' club, facilities should be improved and that the club should show greater community involvement.[22] At this time, whilst the FSA examined the overall picture of football, there was also a large growth in the number of Independent Supporters' Associations (ISA) at individual clubs. According to Russell, an ISA's main aim was to evade the club-supporter relationship that had traditionally been the topic of fan dissatisfaction, and move towards giving fans greater involvement and inclusion in the game.[23] Thus, part of the role of ISAs 
within football was to protest about the shifting demographics of the modern football crowd, ticket price increases, and the changing nature of the match day experience.

At the same time, however, there were methods put in place to include supporters more through the development of Football in the Community Schemes across the country. This began through a pilot scheme in the North West of England in 1986 which was established as part of The Footballers' Further Education and Vocational Training Society Limited (FFE\&VTS) and it quickly became a successful new venture between clubs and the local community. This success continued into the 1990s where further funding from The Football Trust (later re-established as the Football Foundation) allowed it to develop at all ninety-two league clubs. Indeed, the developing relationship between clubs and the local community has seen the projects widen to tackle issues such as social inclusion, education and health.[24]

Over time, the partial involvement of supporters was deemed successful and it was felt that clubs could do more to include fans and benefit from their overall involvement. To begin this process, the government established a channel for supporter involvement and inclusion through the development of a new initiative, called Supporters Direct, to promote corporate governance within football.[25] This new initiative broke the historical exclusion football fans had faced in strategic-making matters, as it provides legal and practical assistance for fans that establish Supporters' Trusts and become involved in the day-to-day running of a football club. As Morrow suggests, this responsibility provides those supporters who establish Trusts 'with an opportunity to influence the direction of their club and to have an input into its positioning as an organisation, both in social and business terms'.[26]

According to Hamil et al. Supporters Direct is 'an opportunity to forge a new relationship between supporters, their clubs and the local community', with Oughton et al. stating that this should not be seen as a last resort, but rather be a continuous process where 
the relationship is strengthened.[27] In fact, the brief history of Supporters' Trusts has in most cases been a success. One of the first Supporters' Trusts to be established was at Northampton Town and arose after the club fell into administration in the early 1990s. To keep the club running, Northampton Town Supporters’ Trust paid £105,000 into the club from 1994 to 2001, accruing 31,592 shares (7 per cent) in the process, and has led to them having a representative on the board.[28] Similarly, when Crystal Palace asked its Supporters' Trust for financial assistance in the late 1990s, the club promised them that there would not be any financial return on their donation and the Trust still raised $£ 1 \mathrm{~m}$ in two months.[29] However, despite the success of Supporters’ Trusts at lower levels, the influence they have at the bigger clubs remains questionable as major corporate finance is needed to establish a large number of shares.[30] This is one of the criticisms of Supporters' Trusts as there is a strong correlation between their success and whether or not the club in question is facing serious financial problems.[31]

Furthermore, there are other recent non-Supporter Trust cases of fan inclusion that have made the relationship between a club and its fans stronger. In the early 1990s, Charlton supporters fought a successful seven-year battle to bring the club back to The Valley, even forming a political party to stand in the local election.[32] When a financial shortage nearly cancelled the move, the supporters raised $£ 1 \mathrm{~m}$ in return for free season tickets and a place on the board, and as such allowed for greater inclusion in the club. Moreover, in 1999, Fergus McCann sold his 51 per cent shareholding in Glasgow Celtic to existing shareholders and season ticket holders stating that 'the supporters must make their voice heard in the boardroom and they can only do that by buying shares'.[33]

Despite the relative success of 'active' supporter involvement at some clubs, however, with the amount of money entering the professional game it is not surprising that there have been incidents of bad-decision making, asset-stripping and financial mismanagement, each of 
which has weakened the relationship between individual clubs and fans. For example, when West Ham and Arsenal attempted to get supporters to buy expensive bonds, which would have paid for the post-Taylor Report ground refurbishments, both schemes failed badly and eventually had to be withdrawn.[34] On the other hand, some bond schemes did initially prove popular with over seven thousand Newcastle United supporters purchasing one that was put forward by the club in 1994, guaranteeing them the right to purchase a season ticket in their allocated seat every year. However, in 1999, a previously unmentioned contractual point allowed the club subsequently to inform some supporters that their seat would now be taken up by corporate hospitality boxes.[35]

Another example of supporters feeling excluded occurred when BSkyB tried to take over Manchester United in 1998 for £643m. The thought of selling out to BSkyB led to a group called 'Supporters United Against Murdoch' (SUAM) forming and arguing, via the Mergers and Monopolies Commission, that BSkyB had undervalued the club and were only interested in selling entertainment.[36] The arguments put forward against this takeover eventually led to its refusal on the grounds that it would increase the 'wealth gap' between the richer and poorer clubs, with the more popular ones retaining a greater share of television revenue. However, although some supporters were influential on this occasion, they were less so when the American businessman, Malcolm Glazer, completed a takeover of the club in 2005 despite long-running protests. Brown notes how this led to the establishment by a number of disgruntled supporters of a new football club, FC United of Manchester, with its agenda stressing the need to 'maintain or re-establish the community' and to be 'an example of how to bring football back to ordinary people’.[37]

Although all of these highlight the contrasting relationship between clubs and their supporters, perhaps the most striking recent example of a complete failure is Wimbledon Football Club. As a result of falling attendances the club decided to move away from Selhurst 
Park (the ground it shared with Crystal Palace) and re-locate to Milton Keynes and thus undermine the relationship between the club and its local community. This unpopular decision led to the establishment of the Wimbledon Supporters' Trust almost immediately who argued that 'their' club had been stolen from them. Indeed, the success of this Trust led to the establishment of a new team, AFC Wimbledon, a six-figure opening sponsorship deal, a stadium to play in and a mass boycott of the re-named MK (Milton Keynes) Dons.

\section{$\underline{\text { Method }}$}

The methods of data collection and analysis adopted for this article were part of wider research which examined the club-fan relationship, the club-media relationship and the fanmedia relationship. The focus of this article is on the club-fan relationship. Data was collected at four football clubs (Aston Villa, Birmingham City, Coventry City and Northampton Town) during the 2002/03 season. Each club was selected as it was based in the Midlands, had different levels of ownership (Aston Villa and Birmingham City were 'listed'), size, income and fan base (Aston Villa averaged over 34,000 compared to 5,000 at Northampton Town). To analyse the relationship at each club a multi-method approach, combining both qualitative and quantitative methods was used, with forty-seven intensive semi-structured interviews of relevant club officials (those involved in the communication process), unofficial external personnel (fanzine and unofficial website editors) and local media personnel (local journalists). An extensive questionnaire survey of eight hundred and twenty-seven supporters was also carried out, containing fifteen closed questions and one open question on how supporters felt the club they supported could improve its communication with them.

The interviews were analysed through a manual form of content analysis. Although content analysis can be used quantitatively to count themes in numerical terms, each subject's responses were coded and categorised, thus providing more depth to the research. As 
suggested by Miles and Huberman, once all of the data had been themed into categories, the analysis began to identify 'patterns and processes, commonalities and differences' within the collected data.[38] The results from the questionnaire survey analysed the patterns emanating from the responses through the use of frequencies and cross tabulations. The open question used in the survey was not coded for statistical purposes until all of the data had been collected and themes/categories began to emerge.[39] In addressing the open question, a majority of those surveyed chose to support how the club currently communicated with them, chose not to say anything or provided feedback on ways the communication process could be improved. Once all of the questionnaires had been analysed each response where feedback was provided was then coded into the following 'fan-club' themes: 'listen to the fans'; 'respect the fans'; 'more fans' forums'; 'keep fans better informed'; more openness and honesty’ and these are highlighted below.

\section{Case Study Findings}

Despite examples where one-way communication remains, there has, in the main, been a more professional approach in the increasing levels of communication emanating from clubs. Many clubs now view corporate communications as important, such as dealing with shareholders, the local community and the general day-to-day queries that arise from supporters and the external media (media sources outside of the club’s control). This has led to the creation of media, marketing or commercial departments within clubs and the employment of people with specific responsibilities in dealing with external communication such as press or media officers. However, this professional approach means very little if clubs do not communicate effectively with their supporters and look at ways of including them more.

An opportunity for this was through the increasing number of internal media sources (media sources that clubs control) available to clubs to communicate and develop two-way 
dialogue with their supporters. Not surprisingly, there were differences in both the amount of internal sources available to communicate with supporters and the number of employees whose responsibility this was at each club. Aston Villa had the largest number of employees responsible solely for communicating externally (six) and it also had the largest number of internal media sources available to do so, including an official website, a match day programme, a club magazine (Claret and Blue), a digital radio station (The 'Villan'), mobile phone texting and regular mail shots and newsletters. Birmingham City had four employees responsible for communicating externally and had a low number of internal media sources in comparison to Aston Villa: an official club website, a match day programme, mobile phone texting and regular mail shots and newsletters. Both Coventry City and Northampton Town had the same number of internal media sources to communicate with their supporters as Birmingham City, but due to extensive cost-cutting in the face of looming administration had a smaller number of employees to do so (Coventry had three and Northampton had two).

In analysing the club-fan relationship further, beginning with Northampton Town, despite working to its disadvantage in certain areas, such as maintaining high levels of information under increasing workload pressures, in other areas having two employees responsible for the club's communication output helped to develop working relationships with the local media and a number of the club's 'active' supporters. Thus, in the main, the two internal employees had managed to control a situation that the majority of supporters and external personnel recognised as being effective, but overall was comparable to its lower league status.

Moreover, the development of a Supporters’ Trust since January 1992 resulting in a supporter being elected onto the board provided an opportunity for realistic and inclusive two-way dialogue to take place. As a result of two-way dialogue being introduced, regular fans' forums (held every six weeks) open to all supporters had been established and were 
well attended by club officials, creating an environment where 'active' supporters felt included as their voice was being heard rather than being dismissed. Even those supporters who could not attend these meetings could contact individuals within the Trust and ask for questions to be raised on their behalf. Indeed, it became apparent how this was also a useful exercise for the club to employ as the media officer stated that he paid,

'close attention to the comments and make sure that they don't do it again [any decisions which both parties agreed had not worked well]...then you can learn from that'.

Therefore, an established Supporters' Trust was advantageous to the club’s 'active' supporters with the fanzine editor of What a Load of Cobblers stating that:

'gone are the days where we [the supporters] are just treated as terrace fodder...fans haven't been fobbed off for the last fifteen years and I think it is because of the growth of things like Supporters' Trusts'.

Although not all confidential information could be disclosed to its supporters, such as potential transfers, it came as no surprise that out of all four clubs, Northampton Town supporters and the club had a more inclusive relationship than the other three clubs. For instance, when the survey asked supporters questions on their relationship with the club through its external communication strategy, three quarters of those surveyed were happy with both the information they received and the ways in which the club communicated with them. In analysing the response of Northampton Town supporters to the open question used in the survey, the main fan-club themes to emerge were the need for more openness and honesty and to keep supporters better informed of club news. Both could be due to the club nearly falling into administration in late 2002 and having to release an appeal to raise $£ 500,000$ to pay off long-term creditors, including the Professional Footballers’ Association and the Inland Revenue. 
At the other three clubs, however, although at least half of the supporters surveyed were happy with the amount of information and communication they received, the results supported research carried out by Beech et al. which indicated that a majority of clubs had failed to develop meaningful links or open up two-way dialogue with their supporters.[40] One of the reasons behind a lack of two-way dialogue through official club websites could be because most clubs utilise the services of the digital media company 'Perform' (previously called Premium TV) to develop a website for them.[41] Under the contract that was signed with the Football League in 2004, the company is responsible for running seventy-six club websites (including some Premier League clubs), with the Football League receiving 80 per cent of any profits made. As part of this contract, football clubs are provided with a range of commercial services that aim to generate revenue from subscription costs, mobile phone texting, betting and advertising. Subscription costs come from a package (called 'World') where supporters can pay a small monthly fee and in return receive a more in-depth focus on the club, which contains things like exclusive interviews, match highlights and an archive of the club’s matches. However, not every supporter has immediate access to the Internet and each club has to constantly review its communication strategy to maintain interest and support amongst its supporter base.

When analysing the relationship at Aston Villa, one of the most striking aspects was the perception amongst supporters that the club did not provide them with an opportunity to feel included. The only evidence of two-way face-to-face dialogue was at its annual shareholder forum (a forum which did not include any top-level club officials). Not surprisingly, this strategy continued to exclude a large majority of 'active' supporters, thus leading to supporter unrest and protestations against the hierarchy of the club. Therefore, the views of the deputy head of media who suggested that the shareholder forum is 'an ideal opportunity to get questions out in the open and any issues that the fans may have' can be 
disputed. In fact, the general reluctance to engage directly with its non-shareholder supporters was further underlined by the official website editor, who stated that:

'sometimes they [the supporters] raise points and say that I would appreciate a reply and then I will get into correspondence [with them] and there are some Villa fans, I'd say approaching fifty that I now correspond with on a regular basis because what they want out of the club is to feel they're being heard and being listened to’.

Whilst the head of media claimed that the club had become victims of its own consistency with regular top ten finishes, the supporters felt that investment needed to be made into the playing side for progress to continually be made. With the chairman and chief executive at the time, Doug Ellis, accused of not attempting to improve the squad it became apparent that direct communication between the club and its fans was limited, with those supporters who wanted to open up dialogue, such as the Aston Villa Supporters' Trust, accused by fellow supporters of 'selling out'. The continued exclusion of supporters was also raised by the Birmingham Post journalist Hyder Jawad:

'In the real world, the masses are calling for regime change. Aston Villa know this but are doing what they always do in times of distress: they put their fingers in their ears and keep their mouths shut...he [Doug Ellis] wears an invisible suit of armour to deflect the derision. It does not seem to worry him that Villa's reputation is crumbling before his prescription spectacles...Ellis listens to those closest to him and ignores the majority'.[42]

Subsequently therefore, this became a catalyst for the unrest felt by a number of 'active' supporters at the club, with a majority of them within the survey referring to the 'fanclub' themes identified earlier such as the need for more openness and honesty, show its supporters' more respect and to establish more fans' forums for them to raise their views in front of club personnel. This is also an area identified by the Premier League survey (2005/06) in the section 'contacts with club'. 'Listening to fans', 'ease of contact by telephone' and 'consulting with fans' each scored quite low and resulted in the club being ranked $18^{\text {th }}$ (out of 20) in terms of listening to fans.[43] Indeed, Williams states that elite 
clubs (such as Aston Villa) lack 'some of the earlier deep-rootedness and cultural and personal commitment traditionally provided by their previously loyal and local core-soccer supporters’.[44]

Even though Aston Villa provided the largest number of internal media sources available to its supporters, it was not surprising that external media sources were utilised more than internal media sources. One of the reasons for this was that elements of the external local media (such as local radio stations BBC WM and Capital Gold/BRMB and the local evening newspaper, the Birmingham Evening Mail) had all developed strategies to include 'active' supporters through two-way dialogue. Indeed, the changing strategy of the local media to provide two-way dialogue with 'active' supporters was also found to apply to the other three clubs. Nevertheless, on a positive note, the introduction of 'The Villan' digital radio station was the main internal media source that encouraged two-way dialogue at Aston Villa through its phone-in programme after every match had finished and on a Monday evening and was well received amongst a number of supporters. Therefore, despite it only being available digitally, if it is used effectively in the future it has the potential to bring supporters closer to the club (such as through links with the official website and the availability of match day commentary). One of the presenters outlined that the club was aware of the importance and potential of using this source to communicate verbally with supporters and this was apparent with regular appearances by the chairmen, some of his directors and the first team manager. In fact, a number of internal employees did see the benefits of communicating better with supporters with the deputy head of media acknowledging that the club’s profile,

'could only be enhanced through better liaison with our supporters and the external media at our disposal'. 
The communication strategy at Birmingham City was more inclusive of supporters than at Aston Villa and had some benefits for the football club. Even though promotion to the Premier League in May 2002 had been achieved just prior to the research process beginning, a number of newly developed initiatives to encourage dialogue with its supporters had already been introduced. In the past, the website editor suggested that the club was 'reactive rather than proactive' and as such had a poor relationship with its fans due to a lack of opportunities for them to communicate and interact with the club. To combat this, fans' forums with key club personnel and a message board on the official website had been established and were well supported, with the official website receiving between three hundred to four hundred messages a day with a personal reply provided to every person who contacted the club.

Equally, and different from the situation at Aston Villa, other internal employees were also supportive of fans expressing their opinions with the editor of the subscription based official website package, 'Blues World', stressing that:

'I always take their views on board because they are the ones who I am trying to reach, they tell me what they want to listen to and what they want to watch and what they want to know...we're an open club that listens to its fans and takes fans [views] on board because there wouldn't be a club if there weren't no fans'.

However, and similarly to Aston Villa, the Premier League survey (2005/06) in its ‘contacts with club’ section scored the club low in comparison to other Premier League clubs (it was ranked $17^{\text {th }}$ with regards to how the club listened to its supporters).[45] Although a majority of supporters were happy with the level of communication received from the club (possibly biased by the euphoria promotion generated at the time), the main 'fan-club' themes emanating from the open question in the survey were the need to show its supporters more respect and to be honest and open with them. 
Although the results from the survey indicated that the initiatives in place to encourage two-way dialogue were proving effective, the match day programme editor claimed that the club could improve this aspect as it was 'not [doing] as much as we can do to be honest'. Indeed, other employees also indicated some limitations with the club's communication strategy. The official website editor indicated that:

'the tools and resources we have at our disposal are not similar to other toplevel clubs, but are, in fact, comparable to some lower-level clubs'.

One of the problems continually stressed by the internal employees was with the role of the press officer as his office was located forty minutes away and he was not employed full-time due to work commitments elsewhere. This approach clearly put pressure on those employees who maintained daily contact with Birmingham City supporters, some of whom felt that not having a full-time club-based press officer affected the local and national profile of the football club. Examining other aspects of the club-fan relationship, one clear difference between Birmingham City and the other three clubs was the lack of 'active' supporter organisations that wanted to challenge and change club policy, either through major protests or by trying to acquire shares and generate a more powerful voice in the club.

At Coventry City, the need for making its supporters feel part of the club was greater than at Birmingham City because it was relegated from the Premier League in 2001 with debts standing at $£ 60 \mathrm{~m}$. The club openly admitted that it did not focus on its supporters at all whilst it was in the Premier League and this complacency can be best summarised with the commercial manager stating:

'as a Premier League club the apparent need for communication appeared to be a lot less, the need to communicate with fans appeared to be a lot less ... there is the scenario of supply and demand which comes into play because your gates are up, your revenues are up, you allow yourself to think that things are fine...the communication going out of the club was more about marketing materials with the aim of selling something as opposed to communicating to get the views of fans and using that kind of information to develop the business'. 
Instead the club relied on annual reports on the Premier League as a guide as to what its supporter base consisted of. Not surprisingly, this philosophy changed after relegation when for the first time the club employed a press officer to improve its external communication and develop ways of including supporters more in the club. The pressing need for this is best summarised by a Supporters' Club representative stating that:

'they've got to start talking to supporters and opening up a dialogue between fans to see how things can be improved. At present there is no relationship at all'.

Although it was continually stressed by club officials that a new 'open and honest' approach had been adopted, it was not surprising that some supporters remained sceptical as to whether this was going to continue in the future. This became evident with the results of the questionnaire stating more open and honesty, more fans' forums and for the club to listen to its supporters, with a high number of Coventry City fans responding to this question.

In fact, even though the club had given its supporters the platform for two-way dialogue through the development of fans' forums, they had not had much to say, thus supporting the notion that there is a lot of audience apathy, or passivity, concerning two-way dialogue. This occurred when an opportunity was provided for the seven thousand season ticket holders to apply to attend a forum early in the 2002/03 season and out of the one hundred and twenty places that were available, only seventy were booked and only fifty-three attended on the night.[46] Referring to this low turnout, the local print journalist, Andy Turner, wrote that in a period where the club deemed communication to be important, this forum was publicised in three of the main sources for news and information at the club (the Coventry Evening Telegraph, Saturday Pink and match day programme) and still received little support amongst arguably the most loyal of supporters:

'a pretty poor show you might think considering City are going out of their way to be more honest and open with their fans by giving them a genuine forum to air their views about how the club is being run and team being 
managed...the response perfectly illustrates the general apathy that exists when the team are doing OK'.[47]

After this, the club decided to have two more fans' forums open to all supporters, attended by clubs officials. Again, these were advertised across the local press and encouragingly over two hundred attended them both. In reality though, the club still had a lot of work to do in building a new relationship with a majority of its supporters. However, the introduction of face-to-face fans' forums and monthly fans' forums on the official club website, where the chairman responded to a selection of questions raised by supporters, did underline the importance that the club placed on two-way dialogue in maintaining both interest and support. The press officer confirmed this by stating how the actual day-to-day dealings with supporters through various communication mechanisms, such as via letters, emails or in person had changed from one where they were largely ignored to one where they each received a personal reply as 'it is important that [our] supporters feel that they have got a voice'.

Therefore, to summarise the research findings, the continuum assessing the changes in the club-fan relationship are now analysed in terms of the level of inclusion or exclusion at the four clubs:

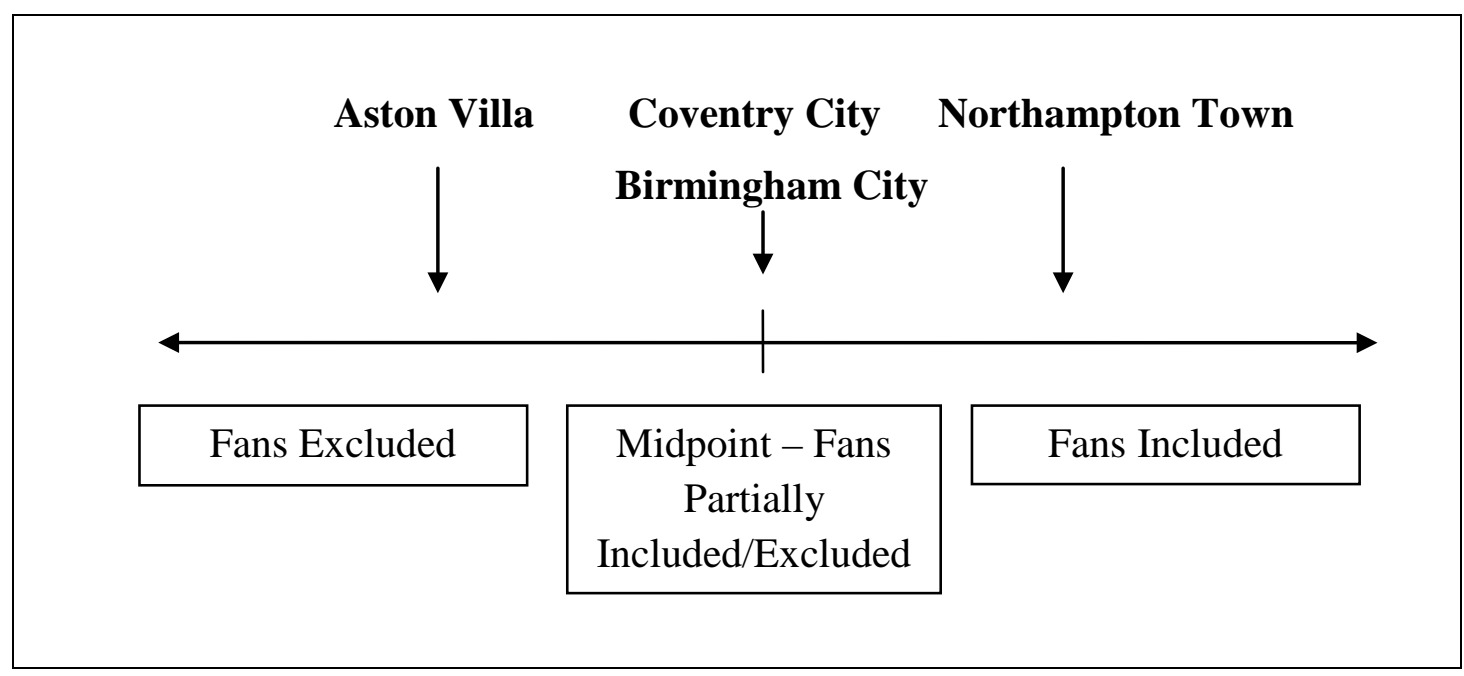




\section{$\underline{\text { Conclusion }}$}

Even though there are important other sources of modern income to football clubs that aid their finances (such as sponsors, advertisers, merchandise, media contracts), all of these income-generators are not possible if a club does not (a) have a healthy relationship with its supporters and (b) encourage them to take an interest in a particular club’s affairs. Despite results often dictating match attendance, the importance of maintaining a healthy relationship between a club and its supporters is imperative because any risk posed by non-attendance would threaten the very existence of any professional club.

Whilst there has been academic attention paid to the media-audience relationship, this article builds upon Redhead's assessment of supporter resistance by offering an empiricallybased analysis of the changing relationship between football clubs and supporters.[48] It has presented many good (and bad) examples of the changing relationship and suggests that one of the key changes centres on the level of inclusion now found in modern football. Even though a majority of fans remain 'passive', the 'active' nature of others has led to greater levels of inclusion at certain clubs (mainly lower level). For instance, the results highlighted a large amount of inclusion at Northampton Town, through to some inclusion at Coventry City and Birmingham City to very limited inclusion at Aston Villa (unless the supporters were shareholders). This supports the views of Holt et al. and Brown who suggested that the large level of corporate finance involved in top-flight clubs makes the supporters influence in decision making matters questionable.[49]

Despite this, there does seem to be a change in strategy amongst clubs at all levels as they realise the importance of two-way dialogue in helping to create a better relationship with their supporters. This has been helped by the development of 'new' media which have dramatically changed the communication landscape within football. On the one hand, this has led to an increase in internal and external sources of communication and, on the other, has led 
to greater opportunities of becoming involved in two-way dialogue. Conversely, this has also changed the nature of the fan 'community'. The changing structure of society has led to an increase in middle-class occupations, with some fans becoming 'active' in consuming and producing their own texts like fanzines and/or unofficial websites. Although clubs still mean a lot to the fan 'community', the changing structure of society and the availability of 'new' media has, therefore, changed the historic working-class football club relationship. Part of this is to do with the changes in employment, urbanisation and the mass media but can also be applied to the increasing number of supporter organisations and the opportunities to watch and debate football on a regular basis.

With all of the changes to the fan-club relationship that this article has presented, every club should remain concerned with the implications that the continued exclusion of some (mainly 'active') supporters could have on its financial situation. If those fans who are deemed to be excluded lose interest in a club, ultimately there could be long-term financial implications, such as the amount of future merchandise purchased, number of visits to the ground, and the level of interest passed on to future generations. Whilst this is a clear concern for those clubs at the lower-levels of professional football, attendances at some Premier League games are also lower than expected.[50] Future research could develop the theme of this article further by investigating whether there are greater possibilities for a more inclusive progressive democracy for 'active' supporters in clubs as a result of the developments in the 'new' media and the increasing level of involvement they encourage from supporters.

\section{Acknowledgements}

I would like to thank Professor Ellis Cashmore, Dr Nigel Thomas and Dr Marc Jones (all at the University of Staffordshire) for their comments on earlier drafts of this article. 
[1] Cannon and Hamil, 'Reforming Football's Boardrooms', 36-46; Lomax, 'How Democracy Saved Northampton Town FC', 102-110.

[2] Giulianotti, 'Supporters, Followers, Fans and Flaneurs: A Taxonomy of Spectator Identities in Football', 25-46; Oughton et al. Back Home - Returning Football Clubs to their Communities; Bower, Broken Dreams: Vanity, Greed and the Souring of British Football.

[3] Laver and Garry, 'Estimating Policy Positions from Political Texts', 619-634; Laver et al. 'Extracting Policy Positions from Political Texts Using Words as Data’, 311-331; Benoit and Laver, Party Policy in Modern Democracies.

[4] Taylor, Football and its Fans, 44-100; Brown, 'United We Stand: Some Problems With Fan Democracy', 50-68.

[5] Russell, Football and the English, 131 and 181-183.

[6] Walvin, The People’s Game: The History of Football Revisited, 164-167.

[7] Ibid, 166-167.

[8] Russell, Football and the English, 182. The old First Division lost 30 per cent between 1960 and 1986 , compared to 50 per cent in the old Division Two, 48 per cent in the old Division Three and 64 per cent in the old Division Four.

[9] See, for example, Fiske, Understanding Popular Culture; Abercrombie and Longhurst, Audiences: A Sociological Theory of Performance and Imagination; Crawford, Consuming Sport: Fans, Sport and Culture; Sandvoss, Fans: The Mirror of Consumption; Horne, Sport in Consumer Culture; Jenkins, Fans, Blogger and Gamers: Exploring Participatory Culture.

[10] Abercrombie and Longhurst, Audiences: A Sociological Theory of Performance and Imagination, 1-40.

[11] Ibid.

[12] Ibid.

[13] Taylor, Football and its Fans; Redhead, The Passion and the Fashion: Football Fandom in New Europe; Haynes, The Football Imagination: The Rise of the Football Fanzine Culture.

[14] Redhead, The Passion and the Fashion: Football Fandom in New Europe, 5-6.

[15] Giulianotti, Football: A Sociology of the Global Game, 146-148; Taylor, 'Giving Something Back: Can Football Clubs and their Communities Co-Exist?' 47-66.

[16] Crawford, Consuming Sport: Fans, Sport and Culture, 19-52.

[17] Ross and Nightingale, Media and Audiences: New Perspectives; Boyle and Haynes, Football in the New Media Age.

[18] Boyle and Haynes, Power Play: Sport, the Media and Popular Culture.

[19] See, for example, Haynes, The Football Imagination: The Rise of the Football Fanzine Culture.

[20] Jary et al. 'Football 'Fanzines' and Football Culture: A Case of Successful Contestation', 584. In a study carried out by When Saturday Comes, there were 22 fanzines in January 1988, 215 in January 1989 and well over 600 by January 1992. By 1990, 87 out of the 92 Football League clubs had at least one fanzine devoted to them (Duke, 'The Sociology of Football: A Research Agenda for the 1990s, 627-645).

[21] The Football Supporters Association was formed in Liverpool in August 1985, three months after the Heysel disaster in Brussels, and one of its main aims was to allow supporters a much closer influence in the decision making process of football clubs (Russell, Football and the English, 230). 
[22] Jary et al. 'Football ‘Fanzines’ and Football Culture: A Case of Successful Contestation’ 581-598.

[23] Russell, Football and the English, 230.

[24] Brown et al. Football and its Communities: Final Report; 'English Professional Football and its Communities’, 159-179; Tacon, ‘Football and Social Inclusion: Evaluating Social Policy’, 1-23.

[25] Corporate governance is where a club’s owners, directors, players, supporters and the local community all interact to determine the objectives and methods of achieving them for a particular football club.

[26] Morrow, The People’s Game? Football, Finance and Society, 52.

[27] Hamil et al. The Changing Face of the Football Business: Supporters Direct, 7; Oughton et al. Back Home - Returning Football Clubs to their Communities.

[28] Lomax, 'How Democracy Saved Northampton Town FC', 102-110.

[29] Jaquiss, 'Mutualism Rules: The Community in Football’, 51-56.

[30] Holt et al. 'The State of the Game: The Corporate Governance of Football Clubs 2004'; Brown, 'Not For Sale'? The Destruction and Reformation of Football Communities in the Glazer Takeover of Manchester United, 614-635.

[31] Holt et al. 'The State of the Game: The Corporate Governance of Football Clubs 2004'.

[32] Everitt, Battle for the Valley.

[33] Carr et al, 'The Celtic Trust', 73.

[34] Fynn and Guest, Out of Time: Why Football Isn't Working, 100-114.

[35] Greenfield and Osborn, Regulating Football: Commodification, Consumption and the Law, 193-194.

[36] Lee, 'Grey Shirts to Grey Suits: The Political Economy of English Football in the 1990s'; Brown, 'Not For Sale'? The Destruction and Reformation of Football Communities in the Glazer Takeover of Manchester United, 614-635.

[37] Brown, 'Not For Sale'? The Destruction and Reformation of Football Communities in the Glazer Takeover of Manchester United, 627.

[38] Miles and Huberman, Qualitative Data Analysis, 9.

[39] Babbie and Mouton, The Practice of Social Research, 233.

[40] Beech et al. 'Towards a Schema for Football Clubs Seeking an Effective Presence on the Internet', 3050 .

[41] Perform was formed by the merger of Premium TV and the Inform Group in 2007 and as part of its service provides the platform and tools that enables clubs to write, manage and develop revenue through the official website.

[42] Jawad, H. ‘Ellis Turns Europe’s Best Into Irrelevance’, Birmingham Post (17 May 2003).

[43] Premier League survey (2005/06) accessed via www.premierleague.com (visited 24 July 2007).

[44] Williams, 'Rethinking Sports Fandom: The Case of European Soccer’, 129.

[45] Premier League survey (2005/06) accessed via www.premierleague.com (visited 24 July 2007).

[46] Turner, A. 'Why So Quick to Jump Ship? Give Him Time: It is Absurdly Early to Write off Gary', Coventry Evening Telegraph (2 October 2002).

[47] Ibid. 
[48] Redhead, The Passion and the Fashion: Football Fandom in New Europe.

[49] Holt et al. 'The State of the Game: The Corporate Governance of Football Clubs 2004'; Brown, 'Not For Sale'? The Destruction and Reformation of Football Communities in the Glazer Takeover of Manchester United, 614-635.

[50] Redhead, 'Those Absent From the Stadium are Always Right: Accelerated Culture, Sport Media, and Theory at the Speed of Light', 226-241.

\section{References}

Abercrombie, N. and Longhurst, B. Audiences: A Sociological Theory of Performance and Imagination. London: Sage, 1998.

Babbie, E. and Mouton, E. The Practice of Social Research. Oxford: Oxford University Press, 2001.

Beech, J., Chadwick, S. and Tapp, A. 'Towards a Schema for Football Clubs Seeking an Effective Presence on the Internet'. European Journal for Sport Management 7, (2000): 30-50.

Benoit, K. and Laver, M. Party Policy in Modern Democracies. London: Routledge, 2006.

Bower, T. Broken Dreams: Vanity, Greed and the Souring of British Football. London: Simon and Schuster, 2003.

Boyle, R. and Haynes, R. Power Play: Sport, the Media and Popular Culture. Harlow: Longman, 2000.

Boyle, R. and Haynes, R. Football in the New Media Age. London: Routledge, 2004.

Brown, A. 'United We Stand: Some Problems With Fan Democracy'. In Fanatics! Power, Race, Nationality and Fandom in European Football, edited by A. Brown. London: Routledge, 1998: 50-68.

Brown, A. 'Not For Sale'? The Destruction and Reformation of Football Communities in the Glazer Takeover of Manchester United. Soccer and Society 8, no. 4 (2007): 614-635.

Brown, A., Crabbe, T. and Mellor, G. Football and its Communities: Final Report. London: Football Foundation, 2006a.

Brown, A., Crabbe, T. and Mellor, G. 'English Professional Football and its Communities'. International Journal of Modern Sociology of Sport 32, no. 2 (2006b): 159-179.

Cannon, T. and Hamil, S. 'Reforming Football's Boardrooms'. In Football in the Digital Age: Whose Game is it Anyway? Edited by S. Hamil, J. Michie, C. Oughton and S. Warby. London: Mainstream, 2000: 36-46.

Carr, P., Findlay, J., Hamil, S., Hill, J. and Morrow, S. 'The Celtic Trust'. In The Changing Face of the Football Business: Supporters Direct, edited by S. Hamil, J. Michie, C. Oughton and S. Warby. London: Frank Cass, 2001: 70-87.

Crawford, G. Consuming Sport: Fans, Sport and Culture. London: Routledge, 2004.

Duke, V. 'The Sociology of Football: A Research Agenda for the 1990s'. The Sociology Review 30, no. 3 (1991): 627-645.

Everitt, R. Battle for the Valley. London: Voice of the Valley, 1991.

Fiske, J. Understanding Popular Culture. London: Unwin Hyman, 1989. 
Fynn, A. and Guest, L. Out of Time: Why Football Isn't Working. London: Pocket Books, 1994.

Giulianotti, R. Football: A Sociology of the Global Game. Oxford: Blackwell, 1999.

Giulianotti, R. 'Supporters, Followers, Fans and Flaneurs: A Taxonomy of Spectator Identities in Football'. Journal of Sport and Social Issues 26, no. 1 (2002): 25-46.

Greenfield, S. and Osborn, G. Regulating Football: Commodification, Consumption and the Law. London: Pluto Press, 2001.

Hamil, S., Michie, J., Oughton, C. and Warby, S. The Changing Face of the Football Business: Supporters Direct. London: Frank Cass, 2001.

Haynes, R. The Football Imagination: The Rise of the Football Fanzine Culture. Aldershot: Arena, 1995.

Holt, M., Michie, J. Oughton, C. and Shailer, L. 'The State of the Game: The Corporate Governance of Football Clubs 2004’. Research Paper No. 3, Football Governance Research Centre. Birkbeck: University of London, 2004.

Horne, J. Sport in Consumer Culture. Basingstoke: Palgrave Macmillan, 2006.

Jaquiss, K. 'Mutualism Rules: The Community in Football'. In The Changing Face of the Football Business: Supporters Direct, edited by S. Hamil, J. Michie, C. Oughton and S. Warby. London: Frank Cass, 2001: 51-56.

Jary, D., Horne, J. and Bucke, T. 'Football 'Fanzines' and Football Culture: A Case of Successful ‘Contestation’’. Sociological Review 39, no. 3 (1991): 581-598.

Jenkins, H. Fans, Bloggers and Gamers: Exploring Participatory Culture. New York: New York University Press, 2006.

Laver, M. and Garry, J. 'Estimating Policy Positions from Political Texts'. American Journal of Political Science 44, no. 3 (2000): 619-634.

Laver, M., Benoit, K. and Garry, J. 'Extracting Policy Positions from Political Texts Using Words as Data'. American Political Science Review 97, no. 2 (2003): 311-331.

Lee, S. 'Grey Shirts to Grey Suits: The Political Economy of English Football in the 1990s'. In Fanatics: Power, Identity and Fandom in Football, edited by A. Brown. London: Routledge, 1998: 32-49.

Lomax, B. 'How Democracy Saved Northampton Town FC'. In The Changing Face of the Football Business: Supporters Direct, edited by S. Hamil, J. Michie, C. Oughton and S. Warby. London: Frank Cass, 2001: 102110.

Miles, M.B. and Huberman, M.A. Qualitative Data Analysis. Thousand Oaks: Sage, 1984.

Morrow, S. The People’s Game? Football, Finance and Society. Basingstoke: Palgrave Macmillan, 2003.

Oughton, C., McClean, M. Mills, C. and Hunt P. Back Home - Returning Football Clubs to their Communities. London: Mutuo, 2003.

Redhead, S. The Passion and the Fashion: Football Fandom in New Europe. Aldershot: Avebury, 1993.

Redhead, S. 'Those Absent From the Stadium are Always Right: Accelerated Culture, Sport Media, and Theory at the Speed of Light'. Journal of Sport and Social Issues 31, no. 3 (2007): 226-241.

Ross, K. and Nightingale, V. Media and Audiences: New Perspectives. Maidenhead: Open University Press, 2003. 
Russell, D. Football and the English. Preston: Carnegie, 1997.

Sandvoss, C. Fans: The Mirror of Consumption. Cambridge: Polity, 2005.

Tacon, R. 'Football and Social Inclusion: Evaluating Social Policy’. Managing Leisure 12, no. 1 (2007): 1-23.

Taylor, N. 'Giving Something Back': Can Football Clubs and Their Communities Co-Exist?' In British Football and Social Exclusion, edited by S. Wagg. London: Routledge, 2004: 47-66.

Taylor, R. Football and its Fans. Leicester: Leicester University Press, 1992.

Walvin, J. The People’s Game: The History of Football Revisited. Edinburgh: Mainstream, 1994.

Williams, J. 'Rethinking Sports Fandom: The Case of European Soccer’. Leisure Studies 26, no. 2 (2007): 127146. 